\title{
REDEFINING NEUTRALITY IN LANGUAGE AND DISCOURSE
}

\author{
Marklen E. Konurbaev \\ The Lomonosov Moscow State University \\ Lenin Hills, $1^{\text {st }}$ Humanities (building 51), Moscow 119899, Russian Federation
}

\begin{abstract}
This paper explores some aspects of functional stylistics with relation to discourse analysis. The basis of every stylistic research is the identification of a set of linguistic elements that determine stylistic variation in a context of speech. Without this basis, every unit of speech may be considered only optionally marked with no ground for the estimation of its relative significance or communicative value. It is argued in the paper based on the theory of 'timbre strings' (Konurbaev 2015) that contextual neutrality is primarily functional rather than purely stylistic in nature. Linguistic elements marked in the dictionary as stylistically marked may remain neutral in the context of stylistically comparable elements as is the case with the Bible or other context heavily fraught with inherently connotative elements. Every instance of stylistic markedness or neutrality can be determined against the broad stylistic background of the context under investigation. Intonation and timbre may serve as a good marker of stylistic hierarchy of elements in speech.
\end{abstract}

Keywords: functional stylistics, cognitive linguistics, functionalism, timbre, neutrality, King James Bible

\section{THE ESSENCE OF STYLISTICS}

The core essence of stylistics is selecting words from the stock of the language and arranging them in a particular order and combination in speech (Akhmanova and Idzelis 1978). However, this choice is not entirely determined by the dictionary meaning of the words alone. Each lexical item during its 'life-time' accumulates a stylistic 'history' of its own: contexts, styles, situations that are collectively considered by the author during the creation process. A word may be absolutely plain and ordinary but the context and syntax may turn this neutrality into a strong aesthetic impact. The opposite is also true. A word, that has a specific stylistic colouring in a dictionary, as, for example, the word 'multitude' marked as biblical in the dictionary, is used almost exclusively to imply plain 'crowd' in the Old Testament of the King James Version. Its aesthetic potential is faded by its stylistic contrast with the biblical allegories and semantically parallel constructions. There is always a certain identifiable intention of the author behind his or her creative schemes of turning neutral lexical stock into marked elements in the context of speech and also in contextually neutralizing the marked elements.

These propositions are a natural development of the theory of functional styles promoted by the outstanding Russian scholar, Professor Victor Vinogradov (Vinogradov 1963; Lipgart 2006; Konurbaev 2002) who profitably extended the premises of the Pra- 
gue Linguistic School concerning the functions of language in speech. According to Havránek (1963), each linguistic item can be either automated in speech, intellectualized or used in a way that allows it to realize its semantic potential to the full (the function of impact). Normally, every act of speech contains linguistic elements that realize all of these functions, but to various degrees, depending on the intention of the speaker. Vinogradov associates the five main functional styles with the domineering function of the linguistic units used in an act of speech. Domineering automation underlays the style of everyday communication; intellectualization is typical of the scientific and official texts; the function of impact predetermines the quality of journalism and fiction.

It follows therefore, that based on the speaker's purport, practically every linguistic element can be either automated, when used at the 'functional background' of the text not involved in an act of forming the core of the message, or foregrounded with the purposes of building the context where the elements of speech may expand their semantic capacity to such an extent that other, related to them contextual elements, form the area of rich and powerful semantic associations (Douthwaite 2000).

Neutral elements in this context are those whose meaning- and style-forming capacity is intentionally played down by the speaker for the benefit of the foregrounded elements. However, such choice of linguistic behavior is not entirely unrestricted, since every element may be relegated by the speaker to the background area only and exclusively by means of establishing the relative stylistic significance between the elements of the text. Once a biblical lexical item is used, for example, it can never stay in the background unless other, stylistically similar elements are used in the same text in whose context the current item will either be foregrounded or relegated to the background.

\section{FUNCTIONAL NEUTRALITY DEFINED}

Neutrality is the lack of cultural specificity, when the reader cannot determine with a degree of certainty in which cultural or attitudinal direction the text is taking him or her and which values it is trying to impart. Ask a foreign student at a university to give his or her estimation of the number of English words he or she knows - and their answer would normally be around $1500-2000$. The next question usually brings them to a psychological halt, 'Can you talk almost on any subject and fully express yourself relying merely on this stock of words?' The answer is usually, 'not sure, but possibly'. Given that the English learner's bilingual dictionary uses slightly above 2500 words to define the remaining sixty thousand, my reply is usually that this means that they probably know the wrong two thousand words that do not allow them to express themselves freely around sixty thousand potential concepts. All right, what are we up to? The question is, 'do style and connotations really matter if we mean to develop the tone and attitude in speech or writing'? Are these not fully determined by syntax and our familiarity with the phenomena of life? 


\section{THE WAY IT WORKS IN THE BIBLE}

We might check it on the basis of a broadly familiar text in two variations - Ecclesiastes 12:

\begin{tabular}{l} 
The Good News Bible (GNT) \\
\hline So remember your Creator while you are \\
still young, before those dismal days and \\
years come when you will say, "I don't en- \\
joy life". \\
2 That is when the light of the sun, the moon,
\end{tabular} and the stars will grow dim for you, and the rain clouds will never pass away.

3 Then your arms, that have protected you, will tremble, and your legs, now strong, will grow weak. Your teeth will be too few to chew your food, and your eyes too dim to see clearly.

4 Your ears will be deaf to the noise of the street. You will barely be able to hear the mill as it grinds or music as it plays, but even the song of a bird will wake you from sleep.

5 You will be afraid of high places, and walking will be dangerous. Your hair will turn white; you will hardly be able to drag yourself along, and all desire will be gone. We are going to our final resting place, and then there will be mourning in the streets.

6 The silver chain will snap, and the golden lamp will fall and break; the rope at the well will break, and the water jar will be shattered.

7 Our bodies will return to the dust of the earth, and the breath of life will go back to God, who gave it to us.

8 Useless, useless, said the Philosopher. It is all useless.
King James Bible (KJB)

Remember now thy Creator in the days of thy youth, while the evil days come not, nor the years draw nigh, when thou shalt say, I have no pleasure in them;

2 While the sun, or the light, or the moon, or the stars, be not darkened, nor the clouds return after the rain:

3 In the day when the keepers of the house shall tremble, and the strong men shall bow themselves, and the grinders cease because they are few, and those that look out of the windows be darkened,

4 And the doors shall be shut in the streets, when the sound of the grinding is low, and he shall rise up at the voice of the bird, and all the daughters of musick shall be brought low;

5 Also when they shall be afraid of that which is high, and fears shall be in the way, and the almond tree shall flourish, and the grasshopper shall be a burden, and desire shall fail: because man goeth to his long home, and the mourners go about the streets:

6 Or ever the silver cord be loosed, or the golden bowl be broken, or the pitcher be broken at the fountain, or the wheel broken at the cistern.

7 Then shall the dust return to the earth as it was: and the spirit shall return unto God who gave it.

8 Vanity of vanities, saith the preacher; all is vanity.

The message is basically the same in the two versions: remember God while you are still young, because when you get old and have no pleasure in life, praising God will seem vain and boring to you. But the language of the King James Bible might inspire awe and adoration and make the reader think of eternity, while The Good News Translation appeals more to reason than emotion, its vocabulary being almost exclusively part of the common stock of Modern English and the imagery and symbolism of the Bible 
without any mercy transformed into plain English. Correspondingly, this change brought about a rather jerky rhythm and practically no pauses between the elements of the former symbolic imagery: 'keepers of the house' vs. 'arms'; 'strong men vs. legs'; 'daughters of music vs. song'; 'grinders vs. teeth', and so on.

\section{NEUTRALITY IS THE WAY 'IT SOUNDS'}

As a result, the diapason of voice and the rhythm become different in the two versions. The GNT is positive, affirmative, matter-of-fact and clear: the domineering contour is descending and low. The text is lexically and semantically clear and causes no slowing down of tempo. The voice is rather low, while the tone rests on the tokens of repetitive instructions. Even the whole of it begins with the business-like 'So'. The narrative types of sentences in the $\mathrm{KJB}$ are the same but the diapason of voice is wide and the contours are longer due to the rhythm which elongates the syntagms on the back of extended metaphors. Hence, the slowing down of tempo necessary for the perception of a very involved symbolism; each symbolic element needs to stand out, because without it the probability of linking them all together into a single image in the mind of the reader gets rather vague with each next turn of the allegory. The semiotic potential of the text is quite high: the reader may not necessarily grasp the meaning of the whole at the very first reading but the symbolic meaning of words associated with eternity on the basis of faith and religion, as well as smooth and sing-song rhythms, syntactic parallelism and the final strong stylistically elevated and rhythmically balanced construction ('vanity of vanities') full of additional semantic implication in the whole book of Ecclesiastes - turn the whole narration into the echoing preaching suitable to be read in the stone buildings.

The timbre structure of the text, as in the case with Ecclesiastes, is not so much dependent on the stylistic characteristics of individual words used by the creators of the text - words could be generally neutral and, when taken separately, will not evoke any cultural or stylistic associations in the reader's mind, but the way these words are made to serve as the tokens of timbre and then form the stylistic impact zones by establishing the relationship between each other to serve the purport of developing the pictorial or auditory image of the text is important.

Rhythm helps, of course. Syntax determines voice. Words are matched with each other in such a manner that no effect of defamiliarization is caused. The image should be whole - smooth and organic. And once the writer begins on a fairly high stylistic note, he or she should keep eyes and ears open to a potential pop-up of undesirable auditory sensations caused by the lack of uniformity where uniformity should be maintained. When the word is made to stand out due to its specific semantic or stylistic connotations - the potential contextual broadening of its semantic scope or the expressive narrowing when the words lose their semantics for the sake of rendering a high expressive tone (incredibly beautiful, outrageously vibrant) - both the writer and the reader should start on a journey to seek the tokens matching this word or a set of words in developing a recognizable image. 


\section{THE HINGES OF STYLE}

The preacher wants to describe old age and chooses to use the metaphor 'keepers of the house'. In a rather long list of words that could be used in this situation there are quite a few lexical units that in essence do not stand out for their unique stylistic colouring: 'head', 'master', 'host', 'overseer', 'controller', 'superintendent', 'organiser', 'manager', 'curator'. However, the functional implications that each of these words have will inevitably evoke in the mind of the reader multiple associations with formal contexts and a limited list of collocations where these words would occur. It was necessary to find relatively neutral lexical units that are unrelated to the recognisable functional contexts and that would be broad enough to be able to collocate with a wide range of words. The chosen chain of tokens seems to be quite successful: 'keeper', 'strong man', 'grinder', 'those that look out of the windows', 'doors', 'daughter of musick'. Some of these words belong to the common stock of English and easily form recognisable collocations in speech (except probably 'daughters of musick' and 'the almond tree' that are even more specific to the general public, but quite easily identifiable by the people of Israel) (Konurbaev et al. 1996).

\section{FUNCTIONAL NEUTRALITY VS STYLISTIC NEUTRALITY}

Writing with neutral words is like drawing with a pencil - images could be rich and deep, but no misuse of colour can spoil the whole impression with undesirable associations. The GNT is also using plain words of the common stock of English. But these do not match the quality of timbre in the KJB which adds just a couple of elements for the voice and timbre to ring a mighty melody in the mind of the reader of the King James Version: allegory, symbolism, rhythm and sound repetition. Even the 'almond tree shall flourish' that may look and sound quite specific to the European eye and ear - signify nothing else but the old age, since this tree blossoms in winter with small white flowers on leafless branches; the local people certainly know of this peculiarity and identify the metaphor immediately. We would even assume it might work as a key to the whole passage unlocking all other metaphors and forming them into a single elevated form. The 'almond tree' to the local people may be not much more unusual than the financial terms to the American public, for whom the description of worldly gain is best presented through this type of lexis:

Good News Bible 11 (GNT)

1 Invest your money in foreign trade, and one of these days you will make a profit.

2 Put your investments in several places many places even - because you never know what kind of bad luck you are going to have in this world.
King James Bible 11 (KJB)

1 Cast thy bread upon the waters: for thou shalt find it after many days.

2 Give a portion to seven, and also to eight; for thou knowest not what evil shall be upon the earth.

The King James Bible with its 'neutral metaphor' based on the words of the common stock of English reaches a much higher power of impact and solemnity of voice than the materialized interpretation of the GNT, that intended to interpret the text for 
the general public and divest it of possible 'complications', but, in fact, bereaved the text of its recognisable voice and timbre and begat 'Moses in a lounge-suit'. Symbolism and extended allegory in the KJB slow down the overall tempo of reading, while association with preaching the eternal truth increases solemnity of timbre and the neutrality of lexis is only a benefit in such voice development. Any shift in this or that narrow conceptual area would become an impediment on the road of allegorical associations.

Neutral, culturally unrelated vocabulary molds new timbres relatively easily when united by an allegory or symbol, but may completely impoverish the narration with the lack of a strong timbre token forming a recognizable image.

Konurbaev (2015) shows that in any kind of writing all words pass a test of prominence: each lexical element introduced in the writing must become either the backdrop or the foreground in the text. Tertium non datur. The so-called stylistic neutrality means cultural and functional indifference. But then comes the moment of choice, when the writer must decide what bricks and mortar to use for his or her own imagery. And once the choice is made in favour of the inherently connotative lexis - immediately the whole host of related functionality starts growing like mushroom spawn and is hurled on the writer to bear. It may be the vocabulary of a narrow conceptual area, terminology, a recognizable name, title or a situation. But it should be consistent with the image the writer is drawing, or it might start falling apart having no reliable conceptual ground to rely on. And the image will have a compositional logic of its own. James Martin (2017) states that "from a relational perspective $<$... $>$ words don't have meaning; rather they do meaning - they mean in relation to the other words that might have been chosen. Similarly, groups and phrases mean in relation to other groups and phrases, clauses in relation to other clauses, exchanges in conversation in relation to other exchanges, phases of discourse is relation to other phases, genres in relation to other genres and so on". Likewise, lexical neutrality may be an issue in stylistics but as concerns the mental representation of the author's voice and timbre — it is subordinated to the formation of mentally complete forms or images and may be contextually marked in terms of timbre or, on the contrary, contextually neutral.

It may sound weird, but the contexts relying on neutral lexis may have a distinctive voice and timbre of their own if the author is successful enough in molding the organic auditory and visual whole in a text; while contexts with marked vocabulary may generally produce the white noise of the stock exchange just minutes before the outburst of a financial crisis, when every sentence 'speaks or shouts' at the same time, but out of tune with the rest of the text; or the visual image is created, but the lexis is too diverse to form into a comprehensible euphony:

Mr Hirsch, known in the 1950s and 1960s for virtuoso performances in Feydeau farces at the Comédie-Française, and later as Nero in Racine's 'Britannicus' opposite Marie Bell, and as Shakespeare's 'Richard III', is an actor of phenomenal physical mobility and comic timing, undimmed by age. His mime of Bernhardt's mother angrily flicking the train of her gown while pleading in a quivering mezzo soprano with her wilful daughter, is a theatrical marvel. His Oscar Wilde, haunted but gallant, is a transformation of tone and physical detail equally magical. Watching this vigorous, seemingly possessed actor at work, you feel that the name of this creaking vehicle ought really to be changed to 'Robert' (Paris theatre, 2002). 
What you might hear in this type of writing is occasional 'cock-a-doodle-doos' from an exorbitantly bright bird exceedingly proud of its linguistic achievements. The stylistic and cognitive mess is caused by the careful avoidance of neutral words that might form together at least some semblance of a backdrop for a good foreground. It has neither context nor plot; neither criticism nor advice; neither is it an ample description of acting or play. Nothing in fact, except a very poor attempt to sound original through the combination of highly unoriginal, incompatible word-combinations that do not go together well. The word 'phenomenal' is an expressive epithet, the word 'physical' is obviously clear and refers to the material condition of objects of reality, the word 'mobility' describes the ability to move around very quickly, the word 'comic' is a literary critical term or the description of something funny and unusual, 'timing' is the ability to do something within the expected period of time, the word 'undimmed' is somewhat unusual in terms of style with the domineering verbal element. However, 'phenomenal physical mobility' is a bit tautological and has never been used either in books or speech before. 'Comic timing' is somewhat vague but relatively clear on abstract terms. But 'phenomenal physical mobility and comic timing, undimmed by age' is an important-sounding meaningless piece of nothing - gobbledygook. But curiously enough, it has voice and timbre in it. The reader will inevitably stop to resolve this quiz and will surely fail. As a result, he or she will hear an empty bravado - phony omniscience that is always pompous, fast and unintelligible.

Add a couple of neutral words, connect them into a semblance of a narration and then link around a token or two - and the voice becomes more narrative and pleasant to listen to. But the description similar to the one above will continue to remain dumb and unreasonably bright:

A man called James Langton was running a repertory theatre at Middlepool that was attracting a good deal of attention; and after Michael had been with Benson for three years, when the company was going to Middlepool on its annual visit, he wrote to Langton and asked whether he would see him. Jimmie Langton, a fat, bald-headed, rubicund man of forty-five, who looked like one of Rubens' prosperous burghers, had a passion for the theatre. He was an eccentric, arrogant, exuberant, vain and charming fellow. He loved acting, but his physique prevented him from playing any but a few parts, which was fortunate, for he was a bad actor. He could not subdue his natural flamboyance, and every part he played, though he studied it with care and gave it thought, he turned into a grotesque. He broadened every gesture, he exaggerated every intonation. But it was a very different matter when he rehearsed his cast; then he would suffer nothing artificial. His ear was perfect, and though he could not produce the right intonation himself he would never let a false one pass in anyone else. 'Don't be natural', he told his company. 'The stage isn't the place for that. The stage is make-believe. But seem natural'. (Maugham 2011).

Well, 'eccentric, arrogant, exuberant, vain and charming fellow' is dark and dumb, but fatness like Rubens' prosperous burghers (timbre token); and 'natural flamboyance ... turning everything into grotesque' (timbre token) — is clear enough. All other language in the passage is neutral and is used as a basis for clear narration. This is an example where neutral words and phrases are authentically neutral and have neither taste not colour. The author lets them stand as a background for the story with no clear cognitive mission. 
Lexical neutrality is a good basis for unconstrained narration in the press. The reason is the freedom of combinability where each neutral word is relatively unrestricted to form very clear and recurrent word-combinations and phrases (Konurbaev 2015). As a result, the story unwinds easily with very few places to slow down. Lexical pairs and oppositions create comfortable endocentric rising-falling contours, that boldly draw the shape of the foregrounded mostly attributive vision of the theatre which is exactly what a good publication might need to promote a theatrical performance in a quality press:

So much theatre is big and juicy. People fall in love and sing about it, or they murder someone and rue the day. But much of life is made of small, modest pleasures (tasty mints, starry nights) and tiny tragedies (an errant comment, an uncomfortable shoe). The real dramas are not easily dramatised. They involve quiet feelings of disappointment or vague questions about what constitutes a meaningful life. These are the concerns, at once existential and banal, that drive the plays of Will Eno. The results are moving and rather funny. (New American theatre 2014).

The voice is shaped by the rising-falling contours ('big and juicy'; 'fall in love and sing'; 'murder and rue'; 'small, modest pleasures and tiny tragedies', 'existential and banal') and mostly affirmative intonations with a slight slowing down in the middle or at the end as the afterthought. It evokes the feeling of an easily told story by a theatre critic who is also a bit of a philosopher and a story-teller who not only analyses but also entertains.

The use of voice and timbre to draw the neutral vocabulary is praised primarily for its freedom of combinations. Neutral words may stay unmarked and uninvolved in the foreground development in the text; or on the contrary be very active in forming the impact zones by creating recognizable cultural patterns. But the fact that this lexis is free from any need to be associated with a particular cultural phenomenon or a specific area of usage, makes this layer of the vocabulary a pliable and convenient instrument in writing on a range of broad or unspecific subjects with the voice of the author being clearly heard.

\section{CONCLUSIONS}

Language acts as a source-code of multiple combinations in speech where message and meaning are ineluctably connected to style and purport. But while pragmatics serves as platform for the analysis of the role of context for the formation of the meaning of each element used in the text (Tomasello and Kecskes 2014), cognitive science relates every instance of language usage in the text to hundreds of external aspects that are not immediately observable in the context of speech but whose presence is invariably felt in the variations and voice and its tone, reflecting the hierarchy of the elements used where the attitude of the speaker or writer is one way or another reflected (Brang 2010).

Expressively strong elements in speech may serve as semiotic triggers that will reunite the words into a meaningful global shape and the whole hierarchy of speech elements may change on the spur of the moment. Every new element of speech will be 
added to this hierarchical map in keeping with the rule of reference where the semiotic trigger will define the position and the relative weight of elements in a speech event. But this may suddenly change the moment a new such trigger appears when the whole hierarchical map will have to be redrawn (Konurbaev 2015).

The opposite of the semiotic timbre-trigger is the neutral word or expression that has the maximum level of automation, which means that the reader barely notices it and his or her eyes slide smoothly from word to word that is instantaneously reflected in the reader's mind as ordinary elements of the unfolding syntactic construction. These automated elements have minimum articulation and the auditory control of individual words is minimized for the benefit of the holistic speech control (Zveginstev 1996). But once the author chooses to surprise the reader or to inhibit him or her to pay special attention to a fact or a phrase - the reader will involuntarily slowdown in order to have a close-up of such word or construction and probably read it again and mentally estimate its weight by comparing and producing the horizontally unlikely matches across paragraphs and pages uttering it half aloud or slightly moving the lips and the tongue and voicing this half-articulation a little. Then you speed up and read on until you reach another timbre-trigger. When the reading exercise is over the reader will involuntarily attempt to shape the whole on the basis of such peaks of attention where the tempo was slow, the rhythm clear and regular and internal articulation - most distinct. As a result, the hearing effect was most ostensible, which in its turn served as a powerful impetus in the cognitive processes where the elements of speech are being actively compared to each other, weighted and arranged into a mental scheme (Konurbaev 2015). Without these processes there is hardly any cognitive process possible. But the peaks and the hierarchy may serve as an excellent basis for mentalese where new cognitive entities are derived computationally by putting together two or three or more elements in order to arrive at a qualitatively new quality of perception - a new cognitive whole (Fodor 2008; Pinker 2013).

(C) Marklen E. Konurbaev, 2017

\section{REFERENCES}

Akhmanova, O. \& Idzelis, R. (1978) What Is The English We Use?: A Course in Practical Stylistics. Moscow: Moscow University Press.

Douthwaite, J. (2000) Towards a Linguistic Theory of Foregrounding. Alessandria: Edizioni del'Orso.

Fodor, J. A. (2008) LOT 2: The Language of Though Revisited. Oxford University Press.

Havránek, B. (1963) Studie o spisovném jazuce in Studies of standard language. Praha.

Kecskes, I. (2014) Word, Context and Communicative Meaning // Вестник Российского университета дружбы народов. Серия: Лингвистика. 2017. Т. 21. № 1. С. 7.

Konurbaev, M.E. (2015) The Style and Timbre of English Speech and Literature. Palgrave MacMillan.

Konurbaev, M., Komarova, A. \& Lipgart, A. (1996) Does It Ring a Bell? (Reopening the Bible for the Occident) // Folia Anglistica: Biblical Studies, \# 1, p. 7 (Moscow: MAX Press). 
Martin, James. The discourse Semantics of Attitudinal Relations: Continuing the Study of Lexis // Вестник Российского университета дружбы народов. Серия: Лингвистика. 2017. Т. 21. № 1. C. $22-47$.

Maugham, W.S. (2011) Theatre (Vintage International). 'New American theatre. Mind the gaps: The super sad, true plays of Will Eno' (2014) in The Economist, April 5 (Economist Newspaper Ltd.).

'Paris theatre. How it's done: A chance to see what acting can be' (2002) in The Economist, October 17 (Economist Newspaper Ltd.).

Pinker, S. (2013) Language, Cognition and Human Nature: Selected Articles. Oxford University Press.

Tomasello, M. (1999) The Cultural Origins of Human Cognition. Cambridge, Massachusetts, London, England: The Bradford Book, The MIT Press.

Tomasello, M. (2014) A Natural History of Human Thinking. Cambridge, Massachusetts, London, England: Harvard University Press.

Бранг П. Звучащее слово: заметки по теории и истории декламационного искусства / Петер Бранг; пер. с нем. М. Сокольской и П. Бранга. Москва: Языки славянской культуры, 2010. 285 c. [Brang, Peter (2010) Das Klingende Wort. Zu Theorie und Praxis der Deklamationskunst in Russland. Moscow: Yazyki slavianskoi kultury (in Russ).]

Виноградов В.В. Стилистика. Теория поэтической речи. Поэтика. Москва: Изд. АН СССР, 1968. 255 c. [Vinogradov, Viktor (1963) Stylistics. Theory of Poetic Speech. Poetics). Moscow: Izdatel'stvo Akademii Nauk SSS).

Звегинцев В.А. Мыслли о лингвистике. Изд. 2-е. М.: Издательство ЛКИ, 2008 [Zvegintsev, V.A. (1996) Thoughts on Linguistics. Moscow: Moscow University Press. (In Russ).]

Конурбаев М.Э. Стиль и тембр текста. Москва: МАКС Пресс, 2002. 212 с. [Konurbaev, Marklen (2002) Stil' i tembr teksta (The Style and Timbre of Text). Moscow: MAKS Press. (In Russ).]

Щерба Л.В. Опыт лингвистического толкования стихотворений: Воспоминания Пушкина // Избранные работы по русскому языку. М.: Учпедгиз. 1957. [Scherba, L.V. (1957) A case study of the linguistic interpretation of poems: Reminiscence by Pushkin in Selected works on the Russian language, Moscow: Uchpedgiz. 26 - 44. (In Russ).]

Успенский Б.А. Избранные труды, том І. Семиотика истории. Семиотика культуры, 2-е изд. М.: Языки русской культуры, 1996 [Uspensky, В. А. (1996) Izbrannyje trudy. Tom I. Semiotica istorii, Semiotika kultury (Selected works. Vol. 1. Semiotics of History, Semiotics of Art). Moscow: Yazyki Russkoi Kultury (In Russ).]

\section{Article history:}

Received: 20 January 2017

Revised: 18 February 2017

Accepted: 22 February 2017

\section{For citation:}

Konurbaev, M. (2017). Redefining Neutrality in Language and Discourse. Russian Journal of Linguistics, 21 (2), 379-389.

\section{Bio note:}

Marklen E. Konurbaev, Dr, Professor at Department of English Linguistics, Faculty of Philology, Lomonosov Moscow State University. Research Interests: General Linguistics, Linguopoetics, English Phonetics, Phonostylistics, English Bible Studies, Theory and Practice of Translation. Contact information: e-mail: marklen@konurbaev.ru 
DOI: $10.22363 / 2312-9182-2017-21-2-379-389$

\title{
О РАЗГРАНИЧЕНИИ НЕЙТРАЛЬНОСТИ В ЯЗЫКЕ И РЕЧИ
}

\author{
М.Э. Конурбаев \\ Московский государственный университет имени М.В. Ломоносова \\ 119899 Москва, Россия, Ленинские горы, д. 1, стр. 51
}

В статье рассмотрены некоторые аспекты функционально-стилистического анализа в контексте исследований дискурса. В основе любого стилистического исследования лежит необходимость выявления слоя лингвистических единиц, образующих базу стилистической вариативности в контексте речи. Это слой нейтральной лексики, которую академик Л. В. Щерба (1957) образно называл «упаковочным материалом» речи. Без него любая речь теряет стилистический ориентир и не может быть воспринята как ситуативно релевантная. Всякий элемент в такой речи будет произвольно идентифицирован пользователем как маркированный или нейтральный, исходя лишь из словарного значения языковой единицы. Проведенное нами широкое функционально-стилистическое и лингвопоэтическое исследование современных английских текстов (Конурбаев, 2002) показало, что, к примеру, в библейских контекстах (в составе Библии Короля Иакова в сопоставлении с современными переводами Библии), в которых по определению практически каждая вторая единица речи маркирована, тоже возможно отчетливо выявить слой функционально-нейтральной лексики, которая и создает необходимый фон для адекватного, ситуативно-маркированного восприятия широкого контекста речи.

Ключевые слова: функииональная стилистика, когнитивная лингвистика, тембр, нейтральный стиль, стилистическая маркированность, Библия Короля Иакова

\section{История статьи:}

Дата поступления в редакцию: 20 января 2017

Дата принятия к печати: 22 февраля 2017

\section{Для цитирования:}

Konurbaev M.E. Redefining Neutrality in Language and Speech // Вестник Российского университета дружбы народов. Серия: Лингвистика. 2017. Т. 21. № 2. С. 379-389.

\section{Сведения об авторе:}

Марклен Эрикович Конурбаев, доктор филологических наук, профессор кафедры английского языкознания филологического факультета МГУ имени М.В. Ломоносова. Сфера научных интересов: общефилологические вопросы, лингвостилистика, лингвопоэтика, фонетика английского языка, фоностилистика, теория и практика перевода. Контактная информащия: e-mail: marklen@konurbaev.ru 